\title{
The Effect of Mannan Oligosaccharide Supplementation on Atlantic Salmon Smolts (Salmo salar L.) Fed Diets with High Levels of Plant Proteins
}

Arkadios Dimitroglou ${ }^{*}$, Patrick Reynolds², Bjarne Ravnoy ${ }^{3}$, Freddy Johnsen ${ }^{4}$, John W Sweetman ${ }^{5 *}$, Johan Johansen² and Simon J Davies ${ }^{1}$

${ }^{1}$ Aquaculture and Fish Nutrition Research Group, School of Biological Sciences, University of Plymouth, Plymouth, PL4 8AA, UK

${ }^{2}$ GIFAS, Gildeskal Forskningsstasjon AS, 8140 Inndyr, Norway

${ }^{3}$ Produs AS, 6924 Hardbakke, Norway

${ }^{4}$ Fishfeed AS, 1929 Auli, Norway

${ }^{5}$ Alltech Aqua, 28200 Lixouri, Kefalonia, Greece

\begin{abstract}
An experiment was conducted to investigate the effect of dietary mannan oligosaccharide (MOS) supplementation on Atlantic salmon (Salmo salar L.) smolts $(\sim 47 \mathrm{~g})$ reared in sea cages. The first treatment (control) consisted of fish fed the basal diet and the second treatment (MOS) fish were fed the same basal diet supplemented with $0.4 \%$ MOS. In the basal diet, $51.8 \%$ of the diet protein was derived from fish meal and $48.2 \%$ from vegetable protein (e.g. soy and wheat). After 14 weeks feeding on the experimental diets the results demonstrated that MOS supplementation did not affect growth performance, however, body protein composition was significantly increased. Additionally, liver histochemistry revealed that glycogen deposition in liver tissue increased from $1.80 \pm 0.73 \mathrm{AU}$ in the control fed fish to $2.58 \pm 0.91 \mathrm{AU}$ in the MOS fed fish.

Histology of the anterior intestine demonstrated that MOS supplementation produced a significantly higher absorptive surface of $4.63 \pm 0.62 \mathrm{AU}$ compared to the control fed fish of $3.65 \pm 0.49 \mathrm{AU}$. The microvilli density was also significantly higher in the anterior intestine in the MOS fed fish,12.02 $\pm 5.95 \mathrm{AU}$, when compared to the control fed fish $5.90 \pm 1.53 \mathrm{AU}$. Similar results for the absorptive area and microvilli density were observed in the posterior intestinal region. Microvilli length increased in the posterior intestine from $1.10 \pm 0.18 \mu \mathrm{m}$ in the control group to 1.41 $\pm 0.19 \mu \mathrm{m}$ in the MOS fed fish. Furthermore, counts of sea lice attached to fish and total number of fish infected by sea lice were significantly lower in the MOS fed fish. The present study shows that $0.4 \%$ MOS supplementation was able to improve intestinal morphology, increase carcass protein content and glycogen deposition in the liver.
\end{abstract}

Keywords: Prebiotic; Mannan Oligosaccharide; MOS; Atlantic salmon; Histology; Sea Lice

\section{Introduction}

Growing aquaculture production and the stable global production of fish meal and fish oil combined with concerns over sustainability and cost has seen, over the last five years, significant changes in the formulation of aquaculture feeds with the increasing use of plant proteins as alternatives to fish meal [1-3].

Soybean meal (SBM) has been widely used as a substitute for fish meal because of its competitive price and relative availability compared to fish meal. However, in salmonids, plant protein sources and especially SBM has been demonstrated to induce histological and functional changes to the fish gastrointestinal tract. These have been reported to include enteritis, increased susceptibility to bacterial infection, changes in absorptive cells, increased presence of inflammatory cells, reduction/blocking of endocytic upake, shortening of villi and microvilli [4-10]. These changes have also been observed in other species such as Gilthead sea bream (Sparus aurata L.) [11] and even common carp (Cyprinus carpio L.) during the first few weeks of feeding [12].

Probiotics and prebiotics have been used as functional dietary supplements to reduce susceptibility to disease. Mannan oligosaccharides (MOS) and in particular, Bio-Mos, derived from the cell wall of yeast namely Saccharomyces cerevisiae using a proprietary process developed by Alltech Inc., has been widely used as a dietary supplement to positively influence performance in poultry and swine [13-16] and more recently in aquaculture $[17,18]$. The incorporation of MOS has been shown to affect gut health by reduced pathogen translocation and improved modulation of both humoral and cellular immune function $[19,20]$. These effects have been well documented in terrestrial animals [21,22] and more recently in fish.

In fin fish aquaculture MOS has been shown to improve feed efficiency in Atlantic salmon [23] and growth and immune status in rainbow trout [24,25].
MOS has been shown to modulate the intestinal microbiology $[26,17,18]$, intestinal morphology $[17,18,25,27-29]$ and the innate immune responses $[19,23,24]$.

Burr et al. [30] and Grisdale-Helland et al. [23] showed that MOS influenced the apparent nutrient digestibility and the carcass proximate composition. Grisdale-Helland et al. [23] demonstrated that gross energy was increased with the addition of MOS but crude protein was reduced in fish carcass analysis of salmon but no significant effect was found in feed utilization.

Many pathogens use mannose-specific lectins as a means of binding to the gut epithelium [31]. The ability of MOS, through its mannose receptors to bind to and block the glycoprotein receptors on the pathogen cell surface enables the pathogens to pass through the gut rather than attaching to the intestinal lining $[32,33]$. Indeed, Torrecillas et al. $[19,20]$ demonstrated that MOS was able to reduce pathogen translocation across the intestinal tract of European sea bass (Dicentrarchus labrax).

*Corresponding authors: Arkadios Dimitroglou, Aquaculture and Fish Nutrition Research Group, School of Biological Sciences, University of Plymouth, Plymouth, PL4 8AA, UK, Tel: +30 6973550751; E-mail: arkadios.dimitroglou@gmail.com

John W Sweetman, Alltech Aqua, 28200 Lixouri, Kefalonia, Greece, Tel: + 30 6944554446; E-mail: jsweetman@alltech.com

Received July 05, 2011; Accepted November 05, 2011; Published November 15,2011

Citation: Dimitroglou A, Reynolds P, Ravnoy B, Johnsen F, Sweetman JW, et al (2011) The Effect of Mannan Oligosaccharide Supplementation on Atlantic Salmon Smolts (Salmo salar L.) Fed Diets with High Levels of Plant Proteins. J Aquac Res Development S1:011. doi:10.4172/2155-9546.S1-011

Copyright: (c) 2011 Dimitroglou A, et al. This is an open-access article distributed under the terms of the Creative Commons Attribution License, which permits unrestricted use, distribution, and reproduction in any medium, provided the original author and source are credited. 
Citation: Dimitroglou A, Reynolds P, Ravnoy B, Johnsen F, Sweetman JW, et al. (2011) The Effect of Mannan Oligosaccharide Supplementation on Atlantic Salmon Smolts (Salmo salar L.) Fed Diets with High Levels of Plant Proteins. J Aquac Res Development S1:011. doi:10.4172/21559546.S1-011

Page 2 of 6

Refstie et al. [34] reported that SBM - induced enteritis in the distal intestine of Atlantic salmon could be eliminated by including a dietary supplementation, with a baker's yeast call wall fraction rich in MOS, to a diet with a moderate (14\%) inclusion of solvent -extracted SBM. The diarrhoeic condition associated with feeding SBM was also improved. This coincided with more efficient utilisation of nutrients for growth, and thus faster growth.

However another important factor may be the ability of MOS to strengthen intestinal barrier efficiency through enhanced gut mucus production as has been demonstrated by Torrecillas et al. [35] in sea bass juveniles. MOS fed sea bass juveniles showed reduced gut bacterial translocation after gut inoculation with $V$. anguillarum. An enhancement in the cells secreting acid mucins with a higher density of eosinphilic granulocytes in the gut mucus was observed.Also an improvement in the gut mucus lysozyme activity was reported which possibly related to the reduced in vivo and in vitro gut bacterial location.

The purpose of the present trial was to further investigate the effect of MOS supplementation on growth parameters, nutrient digestibility, carcass proximate analysis and flesh pigmentation using diets where FM was replaced with plant protein sources. In addition, liver and gut samples were examined histologically using both light (LM) and electron (EM) microscopy. Finally, epidermal sea lice infection was also evaluated twice during the experimental period.

\section{Materials and Methods}

\section{Experimental conditions}

The 14 week trial was conducted in the sea cage facilities of GIFAS (Gildeskål Research Station) in Gildeskål, Norway. Eight $125 \mathrm{~m}^{3}$ cuboid net cages were stocked with approximately 200 Atlantic salmon (Salmo salar) smolts fish per cage with four replicates per dietary treatment. The initial weight of the 4 control cages was $47.2 \pm 2.3 \mathrm{~g}$ while the $4 \mathrm{MOS}$ cages had an initial weight of $46.2 \pm 2.5 \mathrm{~g}$. Fish were fed to satiation twice a day with a minimum time interval of $4 \mathrm{~h}$ between the two feedings. In order to facilitate accurate measurement of feed intake feed wastage was collected and added to the feed intake calculation on a daily basis.

Any mortalities were removed daily and the weight recorded. The water temperature was measured at $3 \mathrm{~m}$ depth and during the trial period varied between 8.8 and $15.20 \mathrm{C}$ with seasonand salinity was stable at $30 \mathrm{ppt}$. Fish sampling was conducted on the last day of the experiment (day 98).

\section{Diets}

A basal diet, containing a high level of plant protein, was formulated using fish meal, soy, wheat, sunflower and fish and canola oil which was used as a control diet. The treatment diet was the basal diet with the addition of $0.4 \%$ mannan oligosaccharide (Bio-Mos ${ }^{\circledR}$, Alltech Inc., USA).The dietary formulations and proximate analyses are shown in Table 1 . Thediets were produced by Fiskeriforskning in Bergen using a Wenger type twin screw extruder supplied with standard equipment for grinding, mixing, drying, coating and cooling. The diets contained $0.01 \%$ yttrium oxide $\left(\mathrm{Y}_{2} \mathrm{O}_{3}\right)$ as an inert marker for apparent digestibility measurements.

\section{Sampling weighing and analysis}

At the end of the trial 8 fish per cage were pooled $(n=4)$ and analysed for energy, protein and fat utilisation using standard analytical procedures as recommended by the AOAC [36] i.e. crude protein: Kjeldahl N x 6.25; crude fat: ether extraction; ash: sample at $600^{\circ} \mathrm{C}$. Fish dry matter (DM) was calculated from the weight of sample before and after drying in $105^{\circ} \mathrm{C}$ overnight. Gross energy was measured using a bomb calorimeter and $\mathrm{N}$-free extract (NFE) was calculated as 100 - $\%$ crude protein - $\%$ crude fat - $\%$ crude fibre - $\%$ ash - $\%$ moisture.

\begin{tabular}{|c|c|c|}
\hline Ingredient (\%) & Control diet & MOS \\
\hline Fish meal LT & 32.00 & 32.00 \\
\hline Wheat gluten & 9.00 & 9.00 \\
\hline Soy protein concentrate & 10.00 & 10.00 \\
\hline Soy extracted protein & 6.00 & 6.00 \\
\hline Sunflower meal & 8.00 & 8.00 \\
\hline Wheat & 10.00 & 10.00 \\
\hline Fish oil & 11.00 & 11.00 \\
\hline Canola oil & 10.70 & 10.70 \\
\hline $\mathrm{MAP}^{1}$ & 0.54 & 0.14 \\
\hline $\begin{array}{l}\text { Premixes vitamins \& } \\
\text { minerals }\end{array}$ & 2.40 & 2.40 \\
\hline Carophyll pink & 0.05 & 0.05 \\
\hline Lysin - HCL & 0.20 & 0.20 \\
\hline Methionine & 0.10 & 0.10 \\
\hline Yttrium Oxide & 0.01 & 0.01 \\
\hline MOS & & 0.40 \\
\hline \multicolumn{3}{|l|}{ Diet proximate analysis } \\
\hline Moisture (\%) & 5.7 & 6.3 \\
\hline Protein (\%) & 43.9 & 43.8 \\
\hline Fat $(\%)$ & 26.3 & 26 \\
\hline $\operatorname{NFE}^{2}(\%)$ & 14.7 & 14.2 \\
\hline Fibre (\%) & 1.9 & 2.2 \\
\hline Ash (\%) & 7.5 & 7.5 \\
\hline Astaxanthin in DM (ppm) & 48.8 & 50.2 \\
\hline $\mathrm{DP}^{*}(\mathrm{MJ})$ & 37.74 & 37.51 \\
\hline $\mathrm{DE}^{*}(\mathrm{MJ} / \mathrm{kg})$ & 18.22 & 18.10 \\
\hline $\mathrm{DP} / \mathrm{DE}^{*}(\mathrm{~g} / \mathrm{MJ})$ & 20.72 & 20.72 \\
\hline
\end{tabular}

*DM: dry matter, DP: digestible protein, DE: digestible energy. 'MAP: mono-ammonium phosphate.

${ }^{2} \mathrm{NFE}$ : N-free extract.

Table 1: Main ingredients and composition of the experimental diets.

Digestibility: At the end of the trial, all fish per cage were stripped and faeces were collected within $24 \mathrm{~h}$ of the last feeding and immediately frozen at $-20^{\circ} \mathrm{C}$ until analysis. Faecal samples were used to calculate the apparent digestibility coefficients (ADCs) where yttrium oxide was used as inert indigestible marker. The yttrium content of the samples was analysed using ICP-spectroscopy and the $\mathrm{ADCs}$ for the nutrients were calculated using the formula:

$\mathrm{ADC}_{\text {nutrient }}=100-100 \mathrm{x}$ [marker in feed (ppm) / marker in faeces (ppm) $\mathrm{x}$ [nutrient in faeces (\%) / nutrient in feed (\%)].

Flesh pigmentation: Astaxanthin concentration was measured on the Norwegian Quality Cut [37] filet from 8 fish per cage $(n=32)$. The NQC fillet is located between the end of the first dorsal fin and the beginning of the anal fin. Astaxanthin analysis was carried out by Nofima in Norway.

Histology: Liver and intestinal samples from 4 fish per cage $(n=16)$ were retained for histological examination by electron and light microscopy (EM and LM). Intestinal sections from the middle of the small intestine (anterior region) and the middle of the large intestine (posterior region) were taken for both LM and EM analysis. Liver samples were analysed using LM.

Briefly, samples for LM were fixed in $4 \%$ saline formalin, dehydrated in graded ethanol before equilibration in xylene and embedding in paraffin wax as described previously by Dimitroglou et al. [17]. Eight $\mu \mathrm{m}$ transverse sections were cut and stained using alcian blue periodic acid-Schiff staining technique (AB-PAS) [38].

Samples for EM (scanning (SEM) and transmission (TEM)) were fixed according to Dimitroglou et al. [17] using $2.5 \%$ glutaraldehyde with $0.1 \mathrm{M}$ cacodylate acid sodium salt (1:1) solution and $2 \% \mathrm{NaCl}, \mathrm{pH}$ 7.2. Prior to fixation, 
Citation: Dimitroglou A, Reynolds P, Ravnoy B, Johnsen F, Sweetman JW, et al. (2011) The Effect of Mannan Oligosaccharide Supplementation on Atlantic Salmon Smolts (Salmo salar L.) Fed Diets with High Levels of Plant Proteins. J Aquac Res Development S1:011. doi:10.4172/21559546.S1-011

Page 3 of 6

SEM samples were rinsed in $1 \%$ S-carboxymethyl-L-cysteine for $30 \mathrm{sec}$ in order to remove epithelial mucus. SEM samples were dried using a K850 critical point drier (Emithech; Kent, UK) with ethanol as the intermediate fluid and $\mathrm{CO} 2$ as the transition fluid. All samples were mounted on aluminium stubs and coated with gold using a K550 sputter coater (Emithech; Kent, UK), then screened with a Jeol JSM $5600 \mathrm{LV}$ electron microscope at $15 \mathrm{kV}$ (Jeol; Tokyo, Japan). Samples for TEM were post-fixed in $\mathrm{OsO} 4$ for $1 \mathrm{hr}$ and embedded with the standard resin procedure. Resin blocks were sectioned using a diamond knife ( $90 \mathrm{~nm})$. Ultrathin sections from each sample were placed in copper grids and stained with saturated uranyl acetate for $15 \mathrm{~min}$, rinsed with distilled water and post stained with Reynolds lead citrate [39] for $15 \mathrm{~min}$. Sections were screened with a Jeol JSM 1200EX transmission electron microscope at $120 \mathrm{kV}$ (Jeol; Tokyo, Japan).

All images were analysed using Image J version 1.36 (National Institutes of Health, USA). At least 5 images from each sample were analysed. Liver images were analysed for glycogen deposition in the hepatocytes using the ratio of a section stained area (glycogen) and the unstained area, producing arbitrary units (AU). Intestinal images from LM were analysed to determine the perimeter ratio (PR) between the internal perimeter (IP) of the gut lumen (villi and mucosal folding length) and the external perimeter (EP) of the gut (PR = IP/EP, arbitrary units AU) [17]. A high PR value indicates high villi length and / or increase mucosal folding. High magnification (x 20,000) SEM images were analysed in order to measure the density of the microvilli (MD) of the enterocytes on top of the villi.Thus the ratio between the microvilli covered area (F, foreground) to the background ( $\mathrm{B}$, background) was calculated $(\mathrm{MD}=\mathrm{F} / \mathrm{B}$, arbitrary units AU), [10,17]. TEM images (magnification x 20,000) were analysed to measure the microvilli length $[10,17,40]$.

Sea lice attachment on epidermis: At week 5 of the trial, 40 fish per cage were randomly selected and the sea lice were counted. Two copepod parasite species were identified and counted. Lepeophtheirus salmonis (Krøyer), known as common sea lice, were assessed by counting the number of sea lice aslarvae (sedentary stage), pre-adults (including males) and fertile females. Total counts of Caligus elongates (Nordmann) irrespective of life cycle or sex were also taken. The same procedure was repeated two weeks later at week 7 .

\section{Statistics}

Independent samples two-tailed T-test was applied in order to evaluate the effect of feeding MOS to fish. All analysis was carried out using SPSS 15.0 (SPSS Inc., IL, USA) and significance was accepted at the $P<0.05$ level. The results are presented as mean \pm standard deviation. The percentage values from the proximate data results were transformed to ARCSIN values prior to statistical analysis.

\section{Results}

\section{Growth}

The results of the growth study are shown in Table 2. There were no significant differences for the growth parameters at the $\mathrm{P}<0.05$ level.

Analysis of fish body composition showed that the fish fed the MOS supplemented diet contained a significantly $(\mathrm{P}=0.049)$ higher protein proximate composition when compared to the control fed fish: $16.85 \% \pm 0.06$ and $16.75 \%$ \pm 0.84 , respectively. Analysis of energy, fat and dry matter revealed that these parameters were not significantly affected by the dietary treatments (Table 3).

\section{Digestibility}

There were no statistical differences $(\mathrm{P}>0.05)$ between the control and the MOS fed fish with regards to faecal dry matter, energy, protein and fat digestibility (Table 4).

\section{Flesh pigmentation}

Dietary MOS supplementation did not significantly $(\mathrm{P}=0.220)$ affect flesh pigmentation (Table 3) of Atlantic salmon.

\section{Histological examination}

The results of the histological examination of liver glycogen deposition, intestinal absorptive surface area and microvilli morphology are presented in Table 5

Liver sections were stained with PAS method (Periodic Schiff's reagent staining) in order to identify the glycogen deposition in hepatocytes. The results showed that the MOS fed fish significantly $(\mathrm{P}=0.012)$ increased the glycogen deposition in liver tissue from $1.80 \pm 0.73 \mathrm{AU}$ to $2.58 \pm 0.91 \mathrm{AU}$.

LM analysis of the anterior intestine region indicated that the MOS fed fish $(4.63 \pm 0.62 \mathrm{AU})$ produced a significantly $(\mathrm{P}=0.001)$ higher absorptive surface (increased villi length and more complex villi structures) compared with the control fed fish ( $3.65 \pm 0.49 \mathrm{AU}$ ). Similarly, in the posterior intestine region the MOS fed fish $(3.90 \pm 0.66 \mathrm{AU})$ produced a significantly $(\mathrm{P}=0.027)$ increased absorptive surface in comparison with the control fed fish $(3.11 \pm 0.63 \mathrm{AU})$.

SEM micrographs from the anterior part of the intestine showed that MOS $(12.02 \pm 5.95 \mathrm{AU})$ significantly $(\mathrm{P}=0.005)$ increased the microvilli density compared with the control $(5.90 \pm 1.53 \mathrm{AU})$ fed fish (Figure 1). In the posterior intestine region again the MOS fed fish $(10.37 \pm 3.28 \mathrm{AU})$ produced significantly $(\mathrm{P}=0.007)$ increased microvilli density compared to the control fed fish $(6.95$ $\pm 2.12 \mathrm{AU})$

TEM micrographs from the anterior intestine region showed that there was

\begin{tabular}{lll}
\hline Parameter & Control & MOS \\
\hline Initial number of fish & 771 & 771 \\
Final number of fish & 747 & 751 \\
Mortalities & 24 & 20 \\
Initial fish weight $(\mathrm{g})$ & $47.2 \pm 2.3$ & $46.2 \pm 2.5$ \\
Final fish weight $(\mathrm{g})$ & $204.06 \pm 9.58$ & $204.18 \pm 9.96$ \\
Feed intake $(\mathrm{Kg} / \mathrm{cage})$ & $25.28 \pm 1.57$ & $25.39 \pm 1.51$ \\
FCR & $0.86 \pm 0.02$ & $0.86 \pm 0.04$ \\
SGR $(\%)$ & $1.41 \pm 0.09$ & $1.44 \pm 0.10$ \\
\hline
\end{tabular}

$\mathrm{FCR}=$ feed intake $/$ biomass increase

$\mathrm{SGR}(\%)=100$ * $(\mathrm{LN}$ (final weight) $-\mathrm{LN}$ (initial weight) / no of days)

Table 2: Growth performance, nutrient utilization and somatic parameters of Atlantic salmon fed the experimental diets.

\begin{tabular}{lll}
\hline & Control & MOS \\
\hline Fish dry matter (\%) & $29.15 \pm 0.67$ & $29.20 \pm 0.45$ \\
Energy (\%) & $8.21 \pm 0.29$ & $8.27 \pm 0.11$ \\
Protein (\%) & $16.75 \pm 0.06$ & $16.85 \pm 0.06$ * \\
Fat (\%) & $11.35 \pm 0.84$ & $11.48 \pm 0.43$ \\
Flesh pigmentation (ppm) & $2.48 \pm 0.39$ & $2.15 \pm 0.26$
\end{tabular}

*Indicates statistical significant difference between control and MOS fed groups $(\mathrm{P}<0.05)$

Table 3: Whole body final proximate composition of Atlantic salmon fed the experimental diets ( $n=4$ per treatment).

\begin{tabular}{lll}
\hline & Control & MOS \\
\hline Faeces dry matter & $12.24 \pm 0.82$ & $12.78 \pm 0.55$ \\
Digestibility energy & $78.96 \pm 1.42$ & $78.31 \pm 0.95$ \\
Digestibility protein & $85.97 \pm 1.12$ & $85.63 \pm 0.78$ \\
Digestibility fat & $87.08 \pm 1.53$ & $86.91 \pm 1.17$ \\
\hline
\end{tabular}

Table 4: Apparent nutrient digestibility (\%) of fish faecal samples. 
Citation: Dimitroglou A, Reynolds P, Ravnoy B, Johnsen F, Sweetman JW, et al. (2011) The Effect of Mannan Oligosaccharide Supplementation on Atlantic Salmon Smolts (Salmo salar L.) Fed Diets with High Levels of Plant Proteins. J Aquac Res Development S1:011. doi:10.4172/21559546.S1-011

\begin{tabular}{lccc}
\hline \multicolumn{1}{c}{ Parameter } & Region & Control & MOS \\
\hline Liver glycogen $^{1}$ & & $1.80 \pm 0.73$ & $2.58 \pm 0.91^{*}$ \\
\hline Gut absorptive sur- & Anterior gut & $3.65 \pm 0.49$ & $4.63 \pm 0.62^{*}$ \\
face $(\mathrm{PR})^{2}$ & Posterior gut & $3.11 \pm 0.63$ & $3.90 \pm 0.66^{*}$ \\
\hline \multirow{2}{*}{ Microvilli density $^{3}$} & Anterior gut & $5.90 \pm 1.53$ & $12.02 \pm 5.95^{*}$ \\
& Posterior gut & $6.95 \pm 2.12$ & $10.37 \pm 3.28^{*}$ \\
\hline Microvilli length $(\mu \mathrm{m})$ & Anterior gut & $1.94 \pm 0.25$ & $2.13 \pm 0.29$ \\
& Posterior gut & $1.10 \pm 0.18$ & $1.41 \pm 0.19^{*}$ \\
\hline
\end{tabular}

${ }^{1}$ Liver glycogen $=$ Ratio stained $/$ unstained area - arbitrary units

${ }^{2}$ Perimeter Ratio $(P R)=$ Internal perimeter / external perimeter - arbitrary units ${ }^{3}$ Microvilli density $=$ microvilli covered area foreground $/$ microvilli covered area background - arbitrary units

*Indicates statistical significant difference between control and MOS fed groups $(\mathrm{P}<0.05)$.

Table 5: Effect of dietary supplementation of MOS on liver glycogen deposition and intestinal morphology.

\begin{tabular}{llcc}
\hline \multicolumn{1}{c}{ Week 5 } & Sub-group & Control & MOS \\
\hline \multirow{2}{*}{ Lepeophtheirus salmonis } & Fertile females & $3.50 \pm 3.70$ & $0.50 \pm 0.58$ \\
& Pre-adult \& males & $14.25 \pm 17.48$ & $1.75 \pm 2.36$ \\
Caligus elongates (total) & & $5.00 \pm 6.22$ & $0.75 \pm 0.50$ \\
Sum of lice per fish & & $12.00 \pm 3.77$ & $15.00 \pm 3.74$ \\
Number of infected fish & & $34.75 \pm 17.23$ & $18.00 \pm 2.45$ \\
\hline \multicolumn{1}{c}{ Week 7 } & Sub-group & Control & MOS \\
\hline & Fertile females & $1.00 \pm 0.82$ & $0.50 \pm 0.58$ \\
Lepeophtheirus salmonis & Pre-adult \& males & $30.75 \pm 16.56$ & $22.00 \pm 5.94$ \\
& Larvae & $15.00 \pm 10.65$ & $9.25 \pm 3.20$ \\
Caligus elongates (total) & & $12.50 \pm 5.20$ & $8.75 \pm 3.59$ \\
Sum of lice per fish & & $59.25 \pm 17.50$ & $40.50 \pm 5.92$ * \\
Number of infected fish & & $29.75 \pm 4.19$ & $23.00 \pm 1.83$ *
\end{tabular}

*Indicates statistical significant difference between control and MOS fed groups $(P<0.05)$

Table 6: Effect of dietary supplementation of MOS on sea lice infection.

no significant effect of MOS supplementation on microvilli length compared to the control fed fish $(\mathrm{P}=0.168)$. However, in the posterior part of the intestine MOS $(1.41 \pm 0.19 \mu \mathrm{m})$ significantly $(\mathrm{P}=0.008)$ improved the microvilli length when compared to the control $(1.10 \pm 0.18 \mu \mathrm{m})$ fed fish. Additionally, in the anterior intestine region 8 out of 16 fish from the control and 0 from the MOS fed fish had signs of either irregular microvilli distribution or swollen/necrotic enterocytes. No differences were observed between the two treatments with regards to supranuclear vacuoles density within the enterocytes. In the posterior gut region 10 out of 16 fish from the control and only 4 out of 16 from the MOS fed fish had signs of either irregular microvilli distribution or swollen/necrotic enterocytes. In the posterior intestinal region no differences on enterocytes supranuclear vacuolation were observed in either feeding group.

\section{Sea lice attachment on epidermis}

The total number of L. salmonis and C. elongates attached to the epidermis of fish was significant lower, $40.50 \pm 5.92$ in fish fed MOS supplementation at week 7 of the trial when compared to control fed fish, $59.25 \pm 17.50$ (Table 6). Additionally, L. salmonis individual assessment of life stage and sex remained unaffected in both sampling points. In details at week 7 , total attached sea lice on control fish were $59.25 \pm 17.50$ lice per fish and significantly reduced to $40.50 \pm$ 5.92 lice per fish in MOS fed fish $(\mathrm{P}=0.044)$. Additionally, the total number of fish infected by sea lice (irrespective to species, life stage or sex) was significantly reduced by the MOS supplementation at both sampling points. At week 5, 22.75 \pm 5.91fish of the control group and $13.00 \pm 0.82$ fish of the MOS group were
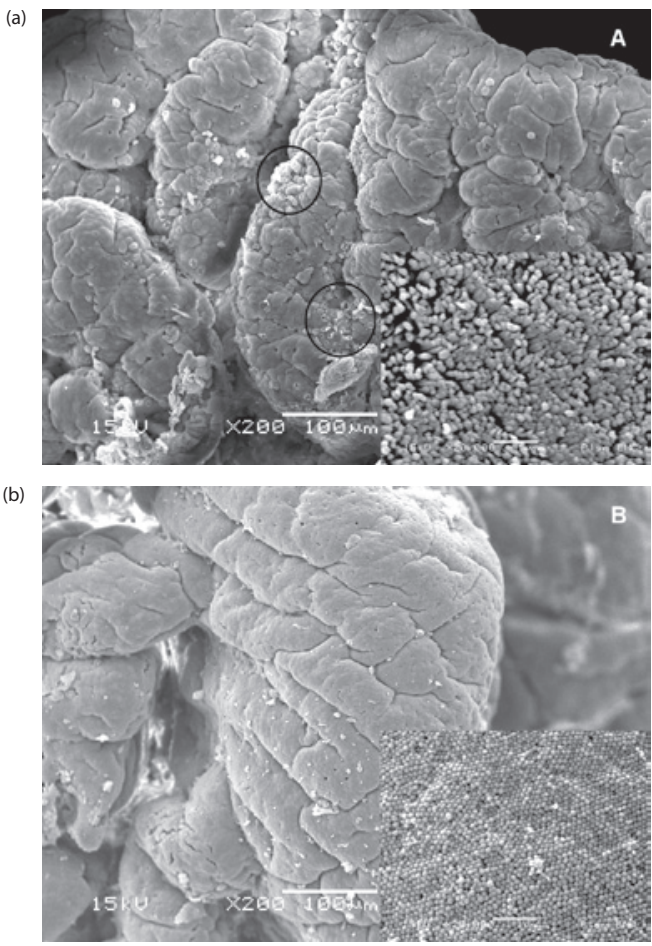

Figure 1: Comparative SEM micrographs from the anterior intestinal region presenting the positive effect of MOS supplementation.Micrograph $\mathrm{A}$ is from a fish from control group whereas the micrograph $B$ is from the MOS treatment.In micrograph $A$, areas of irritation and damaged eneterocytes are presenting within the black cycles. High level magnification (x20000) of microvilli condition is presented on the bottom right corner of each case.

infected by sea lice $(P=0.009)$. At week 7, $29.75 \pm 4.19$ fish of the control fed group and $23.00 \pm 1.83$ fish of the MOS fed group were infected by sea lice (P $=0.013)$.

\section{Discussion}

Currently there is increased research interest on the use of prebiotics in the aquaculture industry $[23,28,30,41]$. The present study was mainly focused on evaluating the effect of MOS on salmon fed with high plant protein diets. Both light and electron microscopy showed that MOS caused significant differences on the gastrointestinal morphology of salmon. MOS supplementation increased the absorptive surface by producing longer mucosal folding in both anterior and posterior gut regions. Similarly, SEM micrographs revealed that MOS supplementation was able to increase the microvilli density in anterior and posterior gut regions. TEM analysis showed that MOS supplementation significantly increased the microvilli length in the posterior gut region.

Literature regarding the effect of MOS on salmon gut histology is scarce; however, Torrecillas et al. [19] assessed the effect of MOS on the gut villi of European sea bass. Dietary administration of MOS at $0.2 \%$ or $0.4 \%$ did not seem to affect villi length. Nevertheless, similar to the findings in the present study, MOS supplementation significantly increased villi folding in rainbow trout, Oncorhynchusmykiss [17,25] and hybrid tilapia, Oreochromis niloticus $x$ O. aureus, [27] using similar dosages of MOS supplementation (0.15\% up to $0.3 \%$ ). Additionally, microvilli length in cobia (Rachycentron canadum) [28] and white sea bream (Diplodus sargus) [29] larvae was increased with $0.2 \%$ of MOS supplementation.

A recent study, using a similar experimental design in sub-adult rainbow trout revealed that $0.2 \%$ of MOS supplementation increased the villi, mucosal 
Citation: Dimitroglou A, Reynolds P, Ravnoy B, Johnsen F, Sweetman JW, et al. (2011) The Effect of Mannan Oligosaccharide Supplementation on Atlantic Salmon Smolts (Salmo salar L.) Fed Diets with High Levels of Plant Proteins. J Aquac Res Development S1:011. doi:10.4172/21559546.S1-011

folding and the microvilli length in both the anterior and posterior intestinal regions compared to the control group [17]. Additionally, in the same study, the microvilli density increased only in the posterior intestinal region of the MOS fed fish when compared to the control fed fish. Similarly, MOS supplementation appears to be more effective in the posterior intestinal region of sea bream where both villi mucosal folding and microvilli density and length were significantly elevated in the MOS fed fish compared to the control fed fish [18]. An improvement in gut morphology is not only likely to benefit feed utilization but the maintenance of a healthy mucosal epithelium reduces the chances of opportunistic indigenous bacterial infections. This may have been a contributory factor to the improved growth performance, feed utilization and survival of rainbow trout [24], European sea bass [19] and green tiger prawn, Penaeus semisulcatus [42] and disease resistance in European sea bass [20,35].

The present results showed that MOS supplementation did not affect the growth performance of salmon smolts which is similar to previous studies using MOS on Atlantic salmon [23], seabream [18], cobia larvae [28], hybrid tilapia [27] and Gulf sturgeon Acipenser oxyrinchusdesotoi [43]. However in contrast, previous studies on rainbow trout [24], European sea bass [19] and green tiger prawn [42] have shown that MOS can improve growth performance.

Apparent digestibility of energy, protein and lipid was not affected by MOS supplementation however in previous studies by Grisdale-Helland et al. [23] on salmon and Burr et al. [30] on red drum, Sciaenops ocellatus, MOS supplementation increased the apparent energy and apparent protein digestibility in fish meal and soybean meal based diets respectively. In the present study, fish carcass composition analysis showed increased protein concentration of the MOS fed fish compared to the control fish. This agrees with studies on rainbow trout [25] and hybrid tilapia [27] using the same level of MOS supplementation (0.4\%). In contrast, larger salmon (starting weight $200 \mathrm{~g}$ ) with higher level of MOS supplementation (1\%) displayed significantly lower carcass protein concentration compared to the control [23]. It appears that either fish size or the level of MOS supplementation is an important factor that may influence the efficacy of MOS induced improvement of carcass composition.

Histological evaluation of the glycogen deposition in the liver tissue revealed that MOS supplementation significantly increased the quantity of glycogen in the hepatocytes. Glycogen stored in hepatocytes can easily be used as an energy source in case of interrupted feeding which may arise in commercial rearing facilities especially during storm conditions.

Sea lice scoring showed that the number of both species of sea lice which attached to salmon was reduced by the dietary MOS supplementation after 7 weeks of feeding. In addition, the total number of fish that were infected by sea lice was significantly lower in the MOS supplemented diet after 5 weeks of feeding. This may be related to the quantity and quality of skin mucus production as it has been shown that MOS enhances the number of cells secreting acid mucins in the gut [35]; these parameters are to be further investigated in future research.

In summary of this study, fish meal was partially replaced by plant protein sources (mainly soy protein) in the experimental diets. MOS supplementation, at $0.4 \%$, improved the liver condition of the salmon which agrees with previous work by Torrecillas et al. [19]. The intestinal morphology was significantly improved with the dietary administration of MOS. MOS did not appear to have any effect on the salmon growth performance. These results suggest that MOS can effectively protect the mucosal epithelium of salmon and possibly reduce the risk of morphological alterations from soy protein.

\section{References}

1. Gatlin III DM, Barrows FT, Brown P, Dabrowski K, Gaylord TG, et al. (2007) Expanding the utilization of sustainable plant products in aquafeeds: a review. Aquac Res 38: 551-579.
2. Refstie S, Asgard TE (2009) Advances in aquaculture feeds and feeding salmonids. In: New technologies in aquaculture: Improving production efficiency, quality and environmental management. Woodhead Publishing Series in Food Science, Technology \& Nutrition No 178.

3. Alsted N (2011) The development of salmon feed. Presented at The Aquaculture and Roundtable Series 2011 (TARS): Aquaculture Feeds and Nutrition, August 17-18 2011, Singapore.

4. BaeverfjordG, Krogdahl A (1996) Development and regression of soybean meal induced enteritis in Atlantic salmon, Salmo salar L., distal intestine: a comparison with the intestines of fasted fish. J Fish Dis 19: 375-387.

5. Krogdahl Å, Bakke-McKellep AM, Røed KH, Baeverfjord G (2000) Feeding Atlantic salmon Salmo salar L. soybean products: effects on disease resistance (furunculosis), and lysozyme and $\operatorname{lgM}$ levels in the intestinal mucosa. AquacultNutr 6: 77-84.

6. Bakke-McKellep AM, Press CM, Baeverfjord G, Krogdahl A, LandsverkT (2000) Changes in immune and enzyme histochemical phenotypes of cells in the intestinal mucosa of Atlantic salmon, Salmo salar L., with soybean mealinduced enteritis. J Fish Dis 23: 115-127.

7. Krogdahl A, Bakke-McKellep AM, Baeverfjord G (2003) Effects of graded levels of standard soybean meal on intestinal structure, mucosal enzyme activities and pancreatic response in Atlantic salmon (Salmo salar L.). AquacultNutr 9: 361-371.

8. Heikkinen J, Vielma J, Kemilainen O, Tiirola M, Eskelinen P, et al. (2006) Effects of soybean meal based diet on growth performance, gut histopathology and intestinal microbiota of juvenile rainbow trout (Oncorhynchus mykiss). Aquaculture 261: 259-268.

9. Uran PA, Schrama JW, Rombout JHWM, Obach A, Jensen L, et al. (2008) Soybean meal-induced enteritis in Atlantic salmon (Salmo salar L.) at different temperatures. Aquacult Nutr 14: 324-330.

10. Merrifield DL, Dimitroglou A, Bradley G, Baker RTM, Davies SJ (2009) Soybean meal alters autochthonous microbial populations, microvilli morphology and compromises intestinal enterocyte integrity of rainbow trout (Oncorhynchus mykiss Walbaum). J Fish Dis 32: 755-766

11. Santigosa E, Penallopis S, Gomezrequeni P, Medale F, Kaushik S, et al. (2005) Effect of fish meal replacement by plant protein sources on non-specific defence mechanisms and oxidative stress in gilthead sea bream (Sparus aurata). Aquaculture 249: 387-400.

12. Uran PA, Goncalves AA, Taverne-Thiele JJ, Schrama JW, Verreth JA, et al. (2008) Soybean meal induces intestinal inflammation in common carp (Cyprinus carpio L.). Fish Shellfish Immunol 25: 751-760

13. Ferket PR, Parks CW, Grimes JL (2002) Benefits of dietary antibiotic and mannan oligosaccharide supplementation for poultry. Proceedings of MultiState Poultry Feeding and Nutrition Conference 14-16 May 2002, Indianapolis, USA.

14. Rosen GD (2007a) Holo-analysis of the Efficacy of Bio-Mos ${ }^{\circledR}$ in Broiler Nutrition. Br Poult Sci 48: 21-26.

15. Rosen GD (2007b) Holo-analysis of the Efficacy of Bio-Mos ${ }^{\circledast}$ in pig nutrition. J Anim Sci 82: 683-689.

16. Rosen GD (2007c) Holo-analysis of the Efficacy of Bio-Mos ${ }^{\circledR}$ in Turkey Nutrition. Br Poult Sci 48: 27-32.

17. Dimitroglou A, Merrifield DL, Moate R, Davies SJ, Spring P, et al. (2009) Dietary mannan oligosaccharide supplementation modulates intestinal microbia ecology and improves gut morphology of rainbow trout, Oncorhynchus mykiss (Walbaum). J Anim Sci 87: 3226-3234.

18. Dimitroglou A, Merrifield DL, Spring P, Sweetman J, Moate R, et al. (2010a) Effects of mannan oligosaccharide (MOS) supplementation on growth performance, feed utilisation, intestinal histology and gut microbiota of gilthead sea bream (Sparus aurata). Aquaculture 300: 182-188.

19. Torrecillas S, Makol A, Caballero MJ, Montero D, Robaina L, et al. (2007) Immune stimulation and improved infection resistance in European sea bass (Dicentrarchus labrax) fed mannan oligosaccharides. Fish Shellfish Immunol 23: 969-981.

20. Torrecillas S, Makol A, Benitez-Santana T, Caballero MJ, Montero D, et al. (2011a) Reduced gut bacterial translocation in European sea bass 
Citation: Dimitroglou A, Reynolds P, Ravnoy B, Johnsen F, Sweetman JW, et al. (2011) The Effect of Mannan Oligosaccharide Supplementation on Atlantic Salmon Smolts (Salmo salar L.) Fed Diets with High Levels of Plant Proteins. J Aquac Res Development S1:011. doi:10.4172/21559546.S1-011

Page 6 of 6

(Dicentrarchus labrax) fed mannan oligosaccharides (MOS). Fish Shellfish Immunol 30: 674-681.

21. Spais AB, Giannenas AI, Florou - Paneri P, Christaki E, Botsoglou NA (2003) Effect of the feed supplement BioMos, a mannan oligosaccharide, on the performance of broiler chickens. J Hellenic Vet Med Society 54: 111 - 118.

22. Miguel JC, Rodriguez-Zas SL, Pettigrew JE (2004) Efficacy of a mannan oligosaccharide (Bio-Mos ${ }^{\circledR}$ ) for improving nursery pig performance. J Swine Health and Production 12: 296-307.

23. Grisdale-Helland B, Helland SJ, Gatlin III DM (2008) The effects of dietary supplementation with mannanoligosaccharide, fructooligosaccharide or galactooligosaccharide on the growth and feed utilization of Atlantic salmon (Salmo salar). Aquaculture 283: 163-167.

24. Staykov Y, Spring P, Denev S, Sweetman J (2007) Effect of mannan oligosaccharide on the growth performance and immune status of rainbow trout (Oncorhynchus mykiss). Aquac Int 15: 153-161.

25. Yilmaz E, Genc MA, Genc E (2007) Effects of dietary mannan oligosaccharides on growth, body composition, and intestine and liver histology of rainbow trout, Oncorhynchus mykiss. Isr J Aquac 59: 182-188.

26. Zhou XQ, Li YL, (2004) The effects of Bio-Mos on intestinal microflora and immune function of juvenile Jain Carp (Cyprinus carpio Var. Jian). In: Nutrition and Biotechnology in the Feed and Food Industries: Alltech's 20th Annual Symposium (Suppl. 1 - Abstracts of posters presented) Lexington, KY, USA.

27. Genc MA, Yilmaz E, Genc E, Aktas M (2007a) Effects of dietary mannan oligosaccharides (MOS)on growth, body composition, and intestine and liver histology of the hybrid tilapia (Oreochromis niloticus $x$ O. aureus). Isr $\mathrm{J}$ Aquac 59: 10-16.

28. Salze G, McLean E, Schwarz MH, Craig SR (2008) Dietary mannan oligosaccharide enhances salinity tolerance and gut development of larval cobia. Aquaculture 274: 148-152.

29. Dimitroglou A, Davies SJ, Sweetman J, Divanach P, Chatzifotis S (2010b) Dietary supplementation of mannan oligosaccharide on white sea bream (Diplodus sargus L.) larvae: effects on development, gut morphology and salinity tolerance. Aquac Res 41: e245-e251.

30. Burr G, Hume M, Neill WH, Gatlin III DM (2008) Effects of prebiotics on nutrien digestibility of a soybean-meal-based diet by red drum Sciaenops ocellatus (Linnaeus). Aquac Res 39: 1680-1686

31. Mirelman D, Ofek I (1986) Introduction to microbial lectins and agglutinins:
Microbial Lectins and Agglutinins, Properties and Biological Activity. John Wiley \& Sons New York.

32. Newman KE, Newman MC (2001) Evaluation of mannan oligosaccharide on the microflora and immunoglobulin status of sows and piglet performance. $J$ Anim Sci 79 (Suppl 1): 189.

33. Fernandez F, Hinto, M, van Gils B (2002) Dietary mannan-oligosaccharides and theireffect on chicken caecal microflora in relation to Salmonella enteritis colonization. Avian Path 31: 49-58.

34. Refstie S, Baeverfjord G, Ripman Seim R, Elvebø O (2010) Effects of dietary yeast cell wall $\beta$-glucans and MOS on performance, gut health, and salmon lice resistance in Atlantic salmon (Salmo salar) fed sunflower and soybean meal. Aquaculture 305: 109-116.

35. Torrecillas S, Makol A, Caballero MJ, Montero D, Ginés R, et al. (2011b) Improved feed utilization, intestinal mucus production and immune parameters in sea bass fed mannan oligosaccharides (MOS). Aquacult Nutr 17: 223-233.

36. Association of Official Analytical Chemists (AOAC) (1995) Official Methods of Analysis (16th ed.), Arlington, VA.

37. NS 9401 (1994) Atlantic salmon: reference sampling for quality measurements Norwegian Standards Association, Oslo.

38. Kiernan JA (1981) Histological and histochemical methods: theory and practice. Pergamon Press Ltd. England, p162-165.

39. Lewis PR, Knight DP (1977) Staining methods for sectioned material (Glauert A.M. ed.). Elsevier/NorthHolland Biomedical press, p43-44.

40. Hu CH, Xu Y, Xia MS, Xiong L, Xu ZR (2007) Effects of Cu2+ exchanged montmorillonite on growth performance, microbial ecology and intestinal morphology of Nile tilapia (Oreochromis niloticus). Aquaculture 270: 200-206.

41. Dimitroglou A, Merrifield D, Carnevali O, Picchietti S, Avella M, et al. (2011) Microbial manipulations to improve fish health and production - a Mediterranean perspective. Fish Shellfish Immunol 30: 1-16.

42. Genc MA, Aktas M, Genc E, Yilmaz E (2007b) Effects of dietary mannan oligosaccharide on growth, body composition and hepatopancreas histology of Penaeus semisulcatus (de Haan 1844). Aquacult Nutr 13: 156-161.

43. Pryor GS, Royes JB, Chapman FA, Miles RD (2003) Mannanoligosaccharides in fish nutrition: effects of dietary supplementation on growth and gastrointestinal villi structure in Gulf of Mexico sturgeon. N Am J Aquac 65: 106-111.
This article was originally published in a special issue, Probiotic \& Prebiotic Applications in Aquaculture handled by Editor(s). Dr. Daniel L. Merrifield, University of Plymouth, UK; Prof. Zhigang Zhou, Chinese Academy of Agricultural Sciences, China 